\title{
4 \\ A Tale of Two National Parks
}

The first Georges River National Park only existed from 1961 to 1967 , but it was a powerful expression of what the river and its foreshores meant to suburban communities. It left a persistent memory of the goals to be won and the threats to be fought off.

For decades, the Georges River communities had had Australia's first national park, the 'Royal', on their doorstep, just to the south, covering a large and varied area in Sutherland Shire from Audley and Waterfall eastwards down rugged escarpments to the coast. While this national park had been established in 1879 as a site for healthy recreation, its area included picnic grounds, boating and ocean swimming sites, as well as bushland recognised as endemic 'bush', iconically Australian and so a welcome contribution to popular floral nationalism. ${ }^{1}$ This Sutherland national park encouraged people across the region to see their own environment more positively.

Discussions about a new national park on the Georges River began in the community and between local government councils from as early as 1944 . Local newspapers reported suggestions from aldermen from Bankstown, Liverpool and Sutherland councils from 1944 to $1946 .{ }^{2}$ A Bankstownbased parks association existed over this time among residents who feared the river shores might be built out and lost to the public. ${ }^{3}$ The discussion

1 Goodall and Cadzow, Rivers and Resilience, 132-34.

2 'Another National Park: Proposed Georges River Scheme', Propeller, 23 March 1944, 1; 'Proposed National Park', Propeller, 5 December 1946, 1; 'Georges River Development: Conference of Councils', Biz, 13 September 1945, 2.

3 'Georges River Banks May Soon become One Big Park Area', St George and Sutherland Shire Leader, 12 October 1961, 7. 
seemed to fade for some years but was reactivated again around 1950 among working-class people living on the northern and southern river shores near East Hills and Picnic Point. Their vision had a particular focus on the river.

The Picnic Point Regatta Association (PPRA) had formed initially to support the rowing regattas held before the war on the straight stretch of the river where sculls, fours and eights would be raced. Most of the residents around the river owned rowboats for fishing for food as well as relaxation. Visitors would come from Bankstown or further afield and as well as picnicking - would hire rowboats from the many boat sheds along the river. Dances were held in the boatsheds and soldiers from the Holsworthy barracks are remembered to have whistled from the south side of the river to get a boat to come across to bring them over for the dance. ${ }^{4}$

During World War II (WWII), the army destroyed or confiscated many of these local boats, fearing, after the intrusion of Japanese submarines into Sydney Harbour in 1942, that the boats could be used by an enemy if there was an invasion along the river. ${ }^{5}$ After the war, fishing still required rowboats but powerboats began to travel the river too, mainly from further downstream, but they contributed to the river being used once again. The new technologies of the war were making themselves felt on the river. The word 'regatta' came to include powerboat races and, soon after, to include water skiing, initially as a theatrical spectacle for audiences but later more competitively. ${ }^{6}$ Both powerboat races and water skiing required straight, deep stretches of water, a condition that was to shape later conflicts. But, in the 1950s, such concerns were still in the future.

None of the PPRA members had powerboats. In the 1940s they seem to have focused on East Hills Park with its picnics and swimming as much as on regattas. Many local people remembered the activities held in the East Hills Park in the interwar period, as recorded in the photographic archive so carefully preserved by Esme Clisby (see Chapter 2).

4 Alf Stills, Eileen Stills and Carol Jacobsen, interview, 22 November 2005.

5 Colin Jacobsen (aka Col Joye), interview, 12 July 2006.

6 'His Hobby is Breaking the Speed Limit', Cumberland Argus, 13 April 1949, 9; 'Warship at Big Yacht Regatta', Sun, 8 February 1953, 43. 


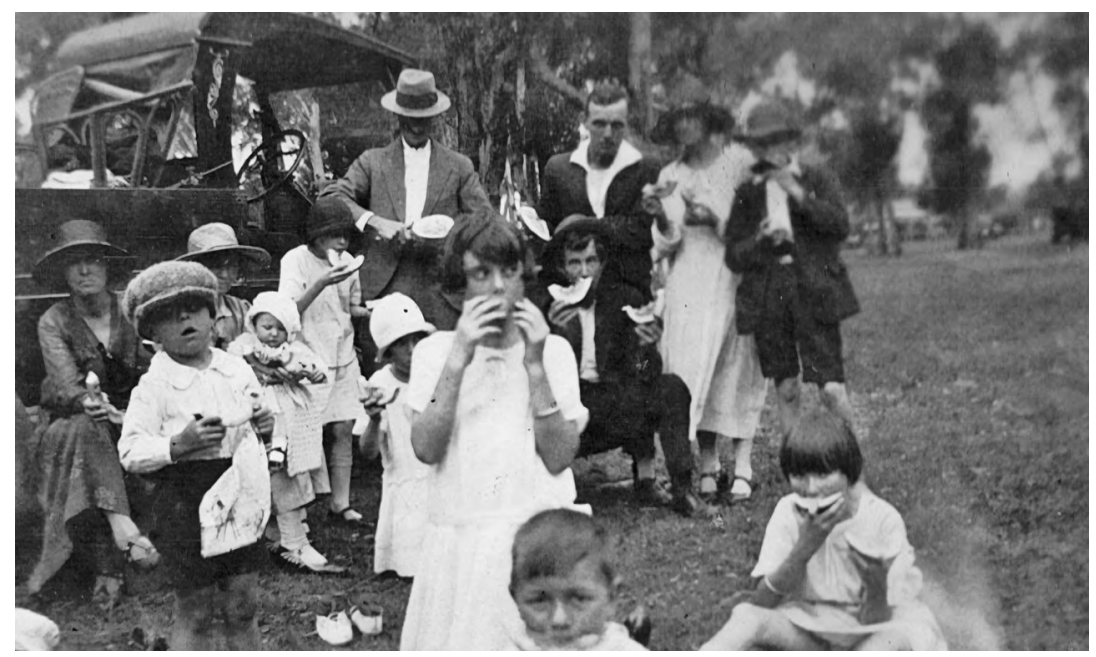

Figure 4.1: Family picnic at the old East Hills Park, 1920s.

Photograph contributed by Esme Clisby.

So it was this wider array of activities that led the PPRA to spearhead the campaign from 1950 to have a large park encompassing both sides of the river. Drawing on the hopes they held from the southern national park, as well as the County of Cumberland Plan proposal to have a green zone stretching all the way to the Georges River, they wanted their Georges River parklands to be recognised as 'national' - that is, with a similar mix of purposes for recreation and enjoyment of the native bush - and set aside for the people - the living, embodied 'nation' - working-class, smallholders, river users and local. ${ }^{7}$

The big pleasure grounds had gone by that time but smaller ones like the Vale of Ah and East Hills Park had hung on. New ways of using the river lands for leisure had emerged with the adoption of golf as a sport. At East Hills, for example, the Bowers family 'improved' their low-lying lands with clearing, infilling and landscaping to create the East Hills Golf Course, without considering that they were destroying a wetland. ${ }^{8}$ The whole area continued to be seen as a holiday location, and 'Picnic Point' well deserved its name. The older activities of swimming and fishing continued on the river itself as well as boating in all its forms, from the old rowing competitions to the newer powerboats with their water skiers attached.

7 PPRA, interview, 22 March 2006; 1958 Annual Report, Picnic Point Regatta Association Archive, Alf Stills Collection (hereafter PPRA Archive).

8 Molloy, The History of Milperra, 71-82, 95-104. 


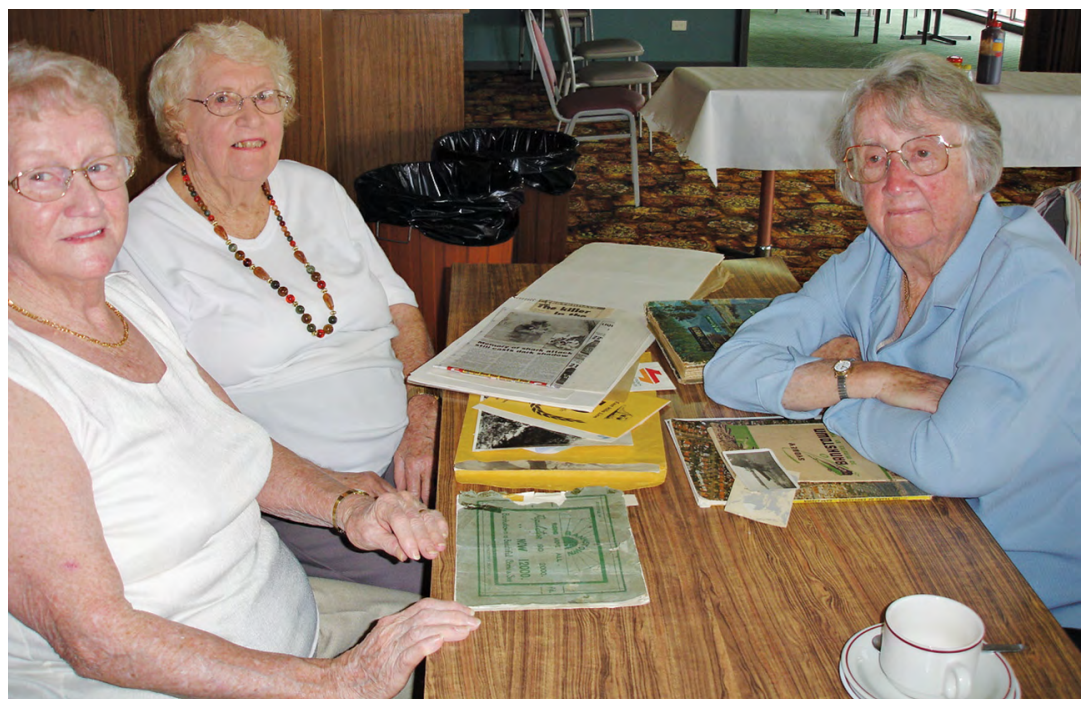

Figure 4.2: Esme Clisby, Eileen Birch, Joy Cornwell, East Hills activist reunion 2006.

Esme Clisby, Eileen Birch and Joy Cornwell share photographs and mementos of the East Hills Park and the Georges River National Park (1961-67) at gathering, Panania RSL, 22 March 2006. Photographer: Heather Goodall.

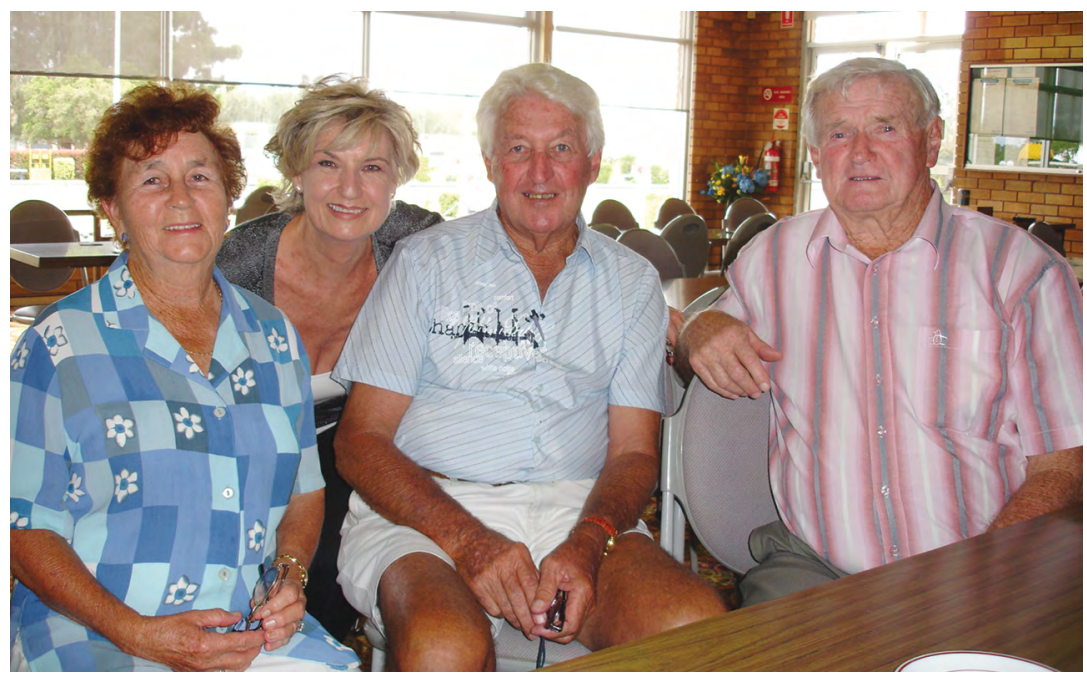

Figure 4.3: Eileen Stills, Carol Jacobsen, Alf Stills, Alan Parnell, East Hills activist reunion 2006.

Eileen Stills (left), Carol Jacobsen (George and Min Jacobsen's daughter), Alf Stills (secretary, PPRA), Alan Parnell, 22 March 2006. Taken at Panania RSL at gathering of East Hills residents and members of the PPRA to share memories of the parklands and the campaign to achieve national park status. Photographer: Heather Goodall. 
Picnics at the East Hills Park and swimming enclosures before and after the war were a key motivation for Esme and many of those who gathered in 2006 to remember the 1950s campaign for the Georges River National Park. ${ }^{9}$

The lives as well as the memories of the key interviewees for this project give a glimpse of the motivations of these campaigners. Alf Stills had been born at Bankstown but when he married in the 1920s, he chose to live near the river because of the fishing. Although he did not row competitively himself, he became the secretary of the PPRA in 1950, as it was this wider use of the river that he valued.

Alf's wife Eileen had grown up on the southern shore of the Georges River opposite East Hills and her three brothers were commercial fishermen.

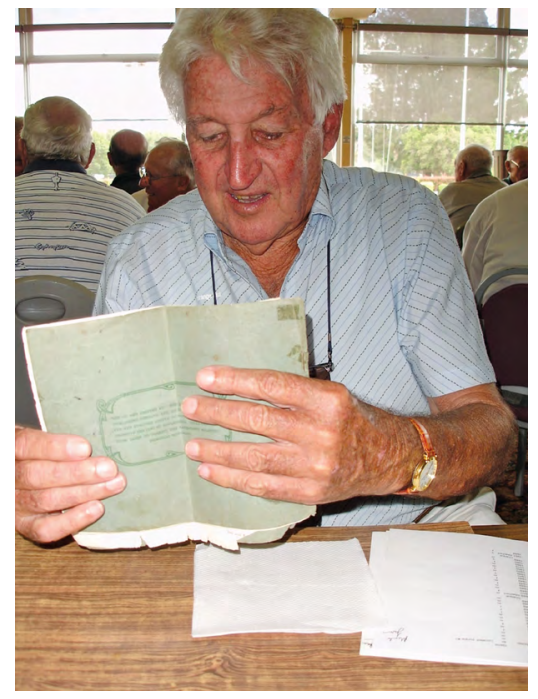

Figure 4.4: Alf Stills, East Hills activist reunion 2006.

Alf Stills with Bankstown souvenir book, 22 March 2006. Alf brought his archive of PPRA membership and correspondence files to contribute to this project. Photographer: Heather Goodall.

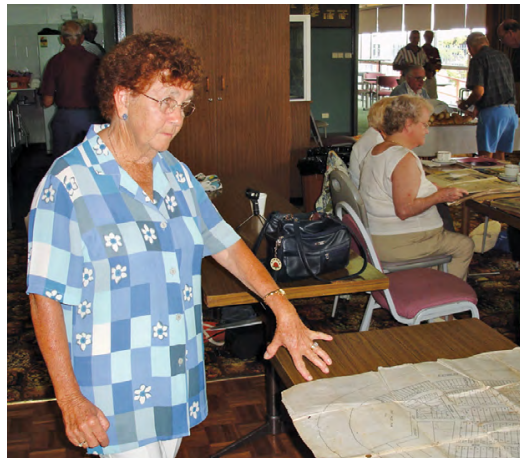

Figure 4.5: Eileen Stills, East Hills activist reunion 2006.

Eileen Stills with map showing East Hills Park and her childhood home on the southern side of the river, opposite the park as well as the Jacobsen's home, 22 March 2006. Eileen's three brothers were all commercial fishermen on the Georges River. Eileen remembered that she often heard music echoing across the river from the Jacobsen home - sometimes because Min Jacobsen was singing through the day or playing the piano for family or community singalongs or later as the family's sons, Col Joye and the Joy Boys, practised for performances. Photographer: Heather Goodall.

9 PPRA, interview, 22 March 2006. 
The other key campaigner was George Jacobsen (c. 1905-1994), who had grown up on another river, the Parramatta, in a childhood he described to his children as being all 'swamp, reeds and fishing'. ${ }^{10}$ George became a cabinet-maker working in the inner city but brought his family to the southern bank of the Georges River in the Depression, then floated his house across the river to set it up at East Hills during the war. He had been on the Bankstown-based parks association initially, in the early 1950s, aiming to expand parkland on the river, but had joined Alf, Eileen and others in the Regatta Association in 1956 as they sharpened their focus on gaining a national park.

George Jacobsen's three sons became well known in the 1960s under the stage name Col Joye and the Joy Boys. Col and Kevin were interviewed with their sister, Carol, and offered valuable insights not only about their father and his campaigning but also about how they remembered growing up on the Georges River. ${ }^{11}$ As Kevin explained his father's commitment:

He was always 'community'-minded ... we didn't realise what it was. But when you think about it, it was the Labor Party in those days used to talk about the local community. But it wasn't politics politics. It was 'what could be done for East Hills?' And then the Progress Association was a similar thing which led to the Picnic Point Regatta, which led to the Georges River Trust. And I remember him going to fight some developers that wanted to develop all along the river. ${ }^{12}$

All the kids spent their spare time on the river. Carol remembered the pool at East Hills Park, a netted tidal enclosure in the river where the small, local community gathered on the intolerable nights in summer when it was too hot to lie on the sheets, too hot to sleep. Col and Kevin both recalled fishing, catching crabs - 'the big mangrove muddies' Col said and prawning in the creek. George's link to the bush was his racing dogs and his dedication to the parks: Kevin remembers walking his father's greyhounds each day.

10 Kevin, Colin and Carol Jacobsen, interview, 12 July 2006.

11 Ibid.; Connell and Seitch, interview, 5 May 2006.

12 Kevin Jacobsen, interview, 12 July 2006. 


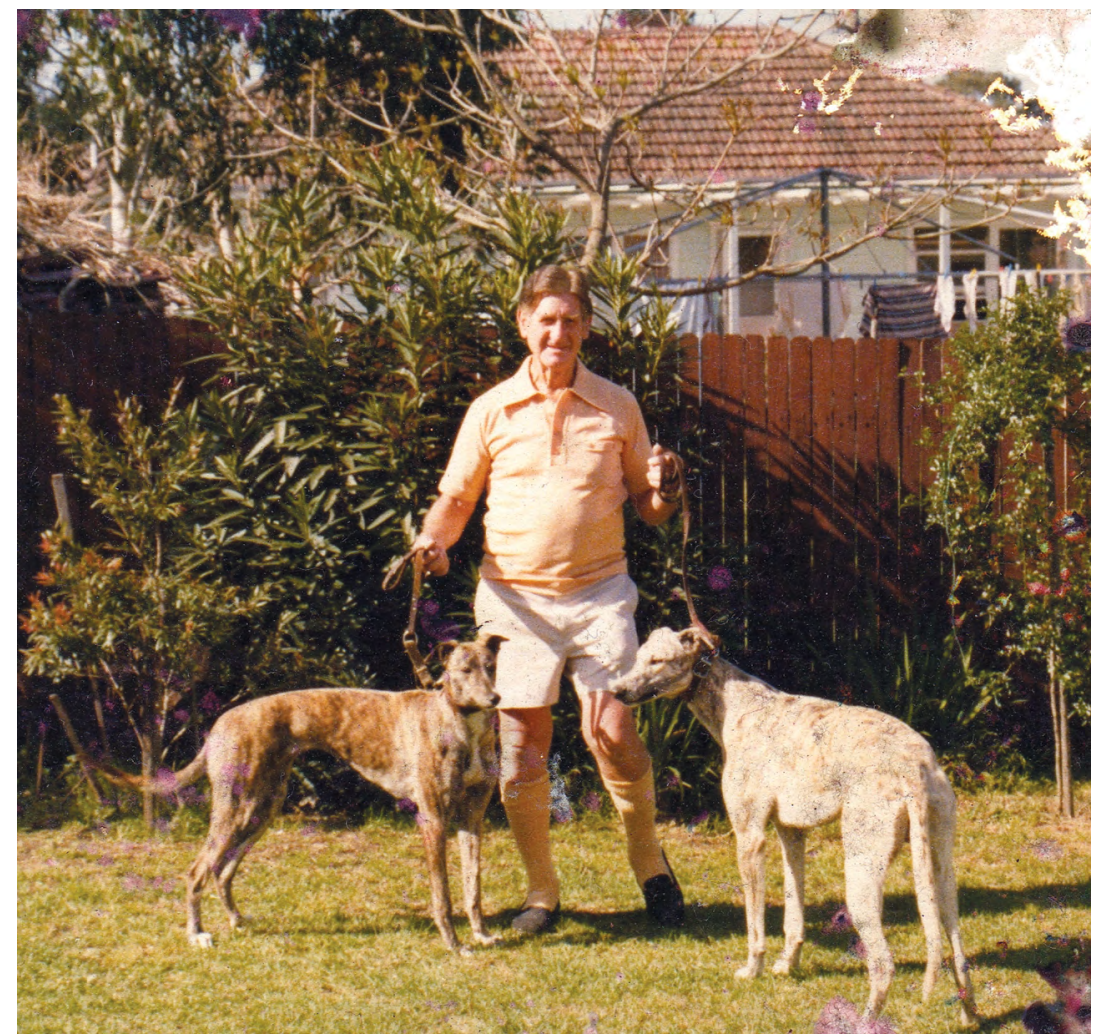

Figure 4.6: George Jacobsen with his racing dogs, in the backyard of his East Hills home, undated c. 1960.

Photograph courtesy of Carol Jacobsen.

The boys learnt from George's father, William, how to shoot birds and rabbits. Col remembered his grandfather as a hard, solitary man, an old railway worker and staunch unionist who had held solid for the union on a three-year strike. William treated people as rogues until they had proved themselves to be otherwise. He never allowed the boys to hunt without reminding them about Aboriginal approaches to the bush:

The mad whitefellas'll end up ruining the world ... You have to look at what the blackfellas did, the way they treated the land. If you catch a bird and kill it, you've got to eat it, no matter what. ${ }^{13}$

13 Kevin, Colin and Carol Jacobsen, interview, 12 July 2006. 
Underlying everything, his family felt that George was committed to the people of East Hills. George wasn't alone in this; he was one of many in these working-class suburbs who were trying to make a community for themselves and their children out of the rubble left after the Depression and the war.

The orientation to the surrounding community was one that George shared with his wife Min. Carol Jacobsen recalled her mother was their 'Rock of Gibraltar'. She was always with the children and didn't go to meetings, unlike George, who was always at one meeting or another. Instead, Min drew all the community into their home and did her community work through her domestic role:

We had a pianola at our place. The thing was to have nights and have everybody around and all sing around the pianola. My mother was the major instigator, even though my father, once you got him up you'd need a crook to get him down, because he wouldn't stop. He was shocking!

But Mum was the one to keep the music going. We always had music in the house. My mother sang every day, all day, as long as I could remember, she never NOT sang, all day.

She always had the house open. We had the cricketers, Mum would have the big bowl of soup and the bloody cricket kids would come home and the soup would be there for them, they'd all be fed. And the footballers.

She had this big industrial sewing machine because she basically made - especially in our area - she made everyone's clothes. She cut everyone's hair, she did everything.

She even used to sew the doubles, made out of cardboard. So you would write the doubles in and then she would sew around the doubles. You'd have to rip it up to see if you'd won. And that's how they helped to get money for the football club. ${ }^{14}$

The local community was at the forefront of the Regatta Association's campaigning, which was focused on trying to regain public ownership of the lands along the river from an early freehold tenure, known as the Lewis Gordon Estate. Although the foreshore had been freely used by

14 Carol Jacobsen (during a conversation with Alf Stills), PPRA, interview, 22 March 2006. 
the public, much of this land, as discussed in earlier chapters, had been granted freehold in the early years of the British colony but was regarded as 'wasteland' so it had never been developed. The PPRA wanted to secure both the section on top of the escarpment to make a sports ground and the section at the foot of the escarpment, the actual river frontage, to ensure it remained as permanently open, public space. What they feared was that the sale of the high area and the lowland would mean that the everyday, working people along the river would be excluded.

The campaigners, like those they spoke for, had chosen to live there: they valued the spaciousness, the sense of freedom from rules and surveillance that access to the river and its environment gave them. George in particular valued the bush; however, although the fact that it was 'native' was important to him, he also made the dusty patches more inviting by planting as much kikuyu grass as he could convince his sons to water - this was an aggressive, exotic grass that, as Colin said, would 'grow up your leg while you stood there'. ${ }^{15}$ The Stills and Jacobsen families' reasons for living in the area were an attachment to the wider landscape of river and bank, rather than of attachment only to their own freehold blocks, even though this was an area that was becoming suburban through these years. Kevin Jacobsen, for example, born in 1934, recalled growing up at East Hills and using the river frequently for fishing, swimming and, particularly, netting prawns in Salt Pan Creek to the east, which he remembered to have been much more accessible in his youth before 'it was all mangroves'. ${ }^{16}$

The engagement with local places, whether land or water - riverbanks, fishing holes, camp sites, dance halls and swimming enclosures - were expressions of their community network, their sociality. Alf and Eileen Stills explained how the long struggle to gain public ownership of the Lewis Gordon Estate had been closely linked to a whole range of community groups who wanted to use the areas or did so already, like the Scouts and Guides. The PPRA had set up a funding stream, raising money by holding dances, running bingo nights and selling the sand that was being dredged from the riverbed after the council had granted them power to lease to sand miners. They planned to use these funds to make 'improvements' on the riverbanks to enable picnics, as 'to have a picnic ground you have to

15 Kevin, Colin and Carol Jacobsen, interview, 12 July 2006.

16 Ibid. 
have toilets'. ${ }^{17}$ But the state government prevaricated about the transfer of the land title, despite it being designated 'green space' under the County of Cumberland Plan. For eight long years, there was no certainty about the transfer. In the meantime, the PPRA disbursed the funds it raised to local organisations, ensuring that, even if the land was not as available as early as they had hoped, the organisations would be healthy enough to take advantage of it when it finally came. ${ }^{18}$

While these were the motives for those who had chosen to live close to the river, like Alf Eileen and George, others who came had had no choice of their own. These were the people 'slum cleared' from the inner city, the assisted migrants and the displaced people. But they also engaged beyond their fence lines to relate to the river and the spaces around it. Judy and Janny Smith came as children to the Herne Bay Housing Commission hostel on the eastern side of Salt Pan Creek when their family was 'slum cleared' from Caroline Street in Redfern. Their parents had decided to come to the city from Wellington in rural central New South Wales for better health care for their mother and better schooling for their kids. But, as Judy explained, coming from Wellington (inland), 'we were river girls', and they spent much of their time down on Salt Pan Creek swimming or fishing and then, when the family moved to a house constructed by the Housing Commission at Green Valley, off the river and upstream, the girls still travelled to the nearest swimming area on the Georges River at Liverpool. ${ }^{19}$

There were many people from crowded inner-city areas, Aboriginal and non-Aboriginal, who were moved to Housing Commission hostels. While most of them, like the Smiths, wanted better quality housing, they had little choice in where they were sent. There were three main hostels, one at west Linfield (Bradfield Park) and two on the Georges River: the one at Herne Bay was the largest and the other was upstream at Hargrave Park, near Warwick Farm. The historian Michael Hogan grew up at the Bradfield Park hostel, and has recorded many people's memories

17 PPRA, interview, 22 March 2006, unidentified speaker in group discussion.

18 Minister for lands to Joe Kelly, local member in state parliament (and one of the people Alf and George lobbied constantly), 16 February 1959. Kelly took up the PPRA demand on their behalf and made written representations to the minister. PPRA Archive, 1948 to 1968.

19 Goodall and Cadzow, Rivers and Resilience, 210-13. Similar experiences were recounted by WANA interviewees: Wafa Zaim, a Lebanese Sunni migrant, and Khali Bibi Hekmat, an Afghani Hazara woman refugee. 
about all the hostels. ${ }^{20}$ As a boy, he envied the young people growing up in Herne Bay and Hargrave Park, who seemed to have much more adventurous lives, but he realised as he grew older that the two Georges River hostels in particular 'had gained a bad public reputation' and were seen as much rougher places with more workingclass residents and more unruly social environments. ${ }^{21}$ Yet, just as it was for the Smith family, the close proximity of the river for fishing, prawning and swimming made the difficult circumstances of the hostel much more tolerable. ${ }^{22}$

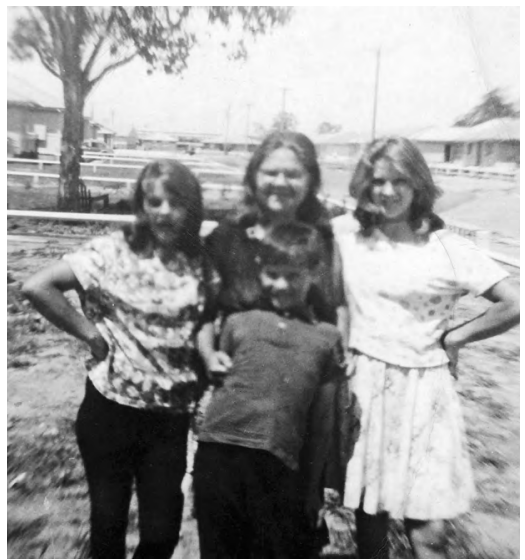

Figure 4.7: Sally Smith with her children, Janny, John and Judy, 1963 , soon after moving from the Herne Bay hostel to Green Valley.

Courtesy of Chester family archive.

The PPRA planned to turn the upper section of the Lewis Gordon Estate, a large area of flat, clifftop land, into a sports field and recreation area. They wanted the lower level of the estate, the strip along the riverbank now known as Burrawang Reach, to remain as 'natural bushland' and to be the 'bush' element of the national park. But the 'green belt' was not strong enough - just as local people had feared - to deliver the Lewis Gordon Estate to the people. Despite the PPRA undertaking long letterwriting campaigns and sustained pressure on state and federal politicians as well as local government, the upper flat area of the Lewis Gordon Estate was, in the end, turned over to the state Electricity Commission to build a substation to service the electricity demands of the modern, electrified homes of the postwar economy, leaving an ugly blank square in the middle of the map of the national park.

20 Hogan 'Postwar Emergency Housing'; Hogan, Almost Like Home.

21 Hogan, 'Postwar Emergency Housing', 16-17.

22 Connell and Seitch, local and Herne Bay residents, interview, 5 May 2006. 


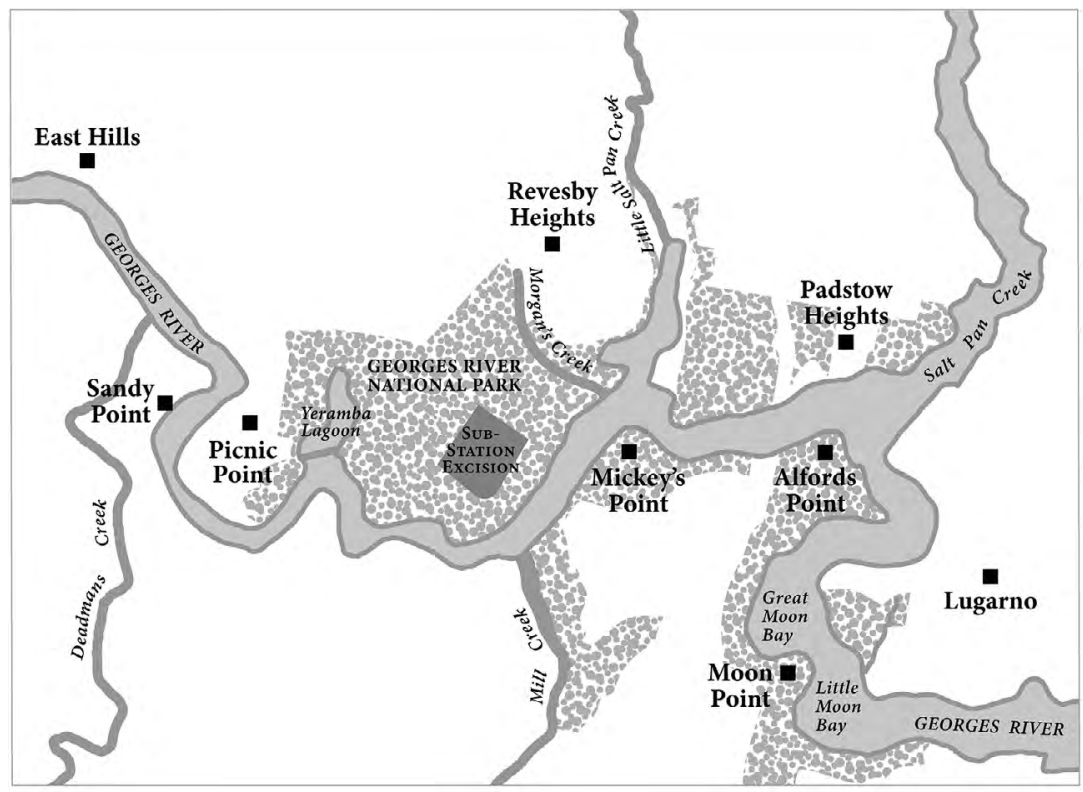

\section{Map 4.1: Georges River National Park, 1961-67.}

The area declared to be the Georges River National Park from 1961 to 1967, based on the Lewis Gordon deceased estate, but only after the excision of a large flat area on the escarpment for an electricity substation to service the expanding population. Three local government councils were involved (Bankstown, Hurstville and Sutherland) and the park was administered by a trust made up of council appointees and local residents. Cartography: Sharon Harrup.

Despite the disappointment of the loss of the upper section, the remainder of the Lewis Gordon Estate was declared as the Georges River National Park in February 1961, with a complicated management structure through a trust involving three large councils (Bankstown, Hurstville and Sutherland). It included areas in each of the three council areas, although most lay in Bankstown Council's jurisdiction. On the northern foreshore, it extended from Salt Pan Creek and Morgan's Creek upstream along the Picnic Point shoreline to Yeramba Lagoon, and on the southern shore it included Mickey's Point (opposite the mouth of Little Salt Pan Creek) and Alfords Point (opposite the mouth of Salt Pan Creek). ${ }^{23}$

23 'National Park Loses Status - and Finance', Bankstown Torch, 23 August 1967, 7. 
Councils - whether municipal or shire bodies - were made up of representatives elected by citizens within divisions of the council area called 'wards'. Councillors were typically most responsive to local businesses, seen to have the potential to increase the area's - and the council's income, and to local organisations that were seen as voicing collective goals. ${ }^{24}$ Funded by state governments as well as by rate collection from landowners, councils were tasked with managing the area's development as well as providing services like road maintenance, sewage collection and garbage disposal. While state governments played a role in each of these processes, the recommendations of local governments were important factors in all such decisions. In the postwar decades, as the Georges River area suffered major population increases and industrialisation, councils could play major roles in environmental politics.

When the 'Royal' had been first set aside in 1879, it was not reserved as 'Crown land'. Instead, the state government had changed the title by vesting the land of the park in the actual individual members of the trust set up to manage it, with these members appointed by invitation from the state government. Trust arrangements for parks and other public places had varied over the years since 1879 , and the 'trust' format was seldom used by 1961. Nevertheless, perhaps due to the sustained public campaign as well as the role of local politicians, the Georges River National Park was to be managed by a trust, although the parklands remained as Crown land and the trust had little real independence. It was to be comprised of representatives of the three local government bodies - two from Bankstown and one each from Hurstville and Sutherland - and officials of the state Lands Department and Planning Authority. There were only three local people appointed as members, one of whom was George Jacobsen who held that position into the later 1970s.

The PPRA collectively swallowed its disappointment at the loss of the potential sporting field, although Alf was still bitter in 2006 about what he saw as a broken promise. Once the national park was declared, the PPRA set about working actively to support the trust and make the remaining area into something that would approximate its aims of fostering sociality along the river. To achieve this, the land along the river needed to be remodelled - not just a toilet block and a few taps but more substantial landfilling and reclamation was needed. The two potential areas were the

24 Gietzelt, Sticks and Stones, gives detailed insight into the political pressures within and on Sutherland Shire Council during the 1960s. 
narrow strip around the base of the escarpment - a strip that came to be called Burrawang Reach - and the rocky mouth of a small creek that flowed into Georges River just west of Burrawang Reach. This area was to be extensively 'reclaimed' to create grassed picnic areas and was called Cattle Duffers Flat, a romantic name that invented an entirely fictional history about the area having once been used, wild and untamed, to hide cattle stolen ('duffed') from nearby settler properties. Both these proposals involved uprooting and destroying stands of the expanding mangroves. This goal opened up a major rift in the PPRA, exposing an emerging concern for the non-human environment.

Alf Stills, still PPRA secretary, was one who wanted to push ahead with the mangrove destruction. Alf did not like mangroves. He had been one of the people who had noticed that they were expanding, explaining to me that, as a young man, he 'did prawning in Salt Pan Creek but it was all mangroves later on'. ${ }^{25} \mathrm{He}$ was driven by a determination that at least some of the Regatta Association's vision would be achieved and he had no qualms about digging up mangroves to do it.

As he described it:

Alf Stills: Our main aim was from the beginning to start a sporting area up top. And we were going to develop from there ... but we couldn't develop the land. But where that picnic area is down there, there used to be a lot of mangroves. We had a lot of trouble developing it, because they reckon we shouldn't have got rid of the mangroves. Well we did, we finally got rid of them. Lot of them put that wall round the river and made it a grassed area. And you can't get near that place down there now, for people!

Interviewer: So there weren't so many mangroves 50 years ago?

Alf Stills: No, no.

Interviewer: ... but the gum trees? Were you interested in keeping some of that around the recreation area?

Alf Stills: Well they wanted to keep the bushland there, they didn't sort of want to chop it all down. ${ }^{26}$

25 Notes taken during PPRA, interview, 22 March 2006.

26 PPRA, interview, 22 March 2006. 
Other members of the National Park Trust held similar views to Alf. Ed Byron was one; he became a trust member after the park was established in the early 1960s and remained on the trust for a decade. He was a town planner and spoke of the other members of the trust - whether from the council or the community - as 'dedicated, genuine, local people'. He was emphatic about the need to remove mangroves, saying: 'We had to destroy the mangroves because they took over everything. They thrive on rubbish, they get the run off and the mangroves thrive on it'. Of the trust's accomplishments, Ed was most proud of the facilities like toilet blocks and picnic tables that facilitated informal social gatherings. His wife, Noeline, interviewed at the same time, was strongly in support of his work on the trust and its focus on fostering family and social gatherings. Noeline, however, did not go to any public meetings. Like Min Jacobsen, she did not see such meetings as accessible to her. For her, the land and river management was all 'a bloke's world'. ${ }^{27}$

One of the people within the PPRA who opposed this mangrove removal was George Jacobsen, as his son Colin recalled:

He was horrified they were taking out the mangroves ... [I thought] What would you worry about mangroves for? I mean I must have been 12 because I can recall the mangroves. He said: 'They're not going to take the mangroves off'. ${ }^{28}$

George lost this battle. The Burrawang Reach and Cattle Duffers' Flat picnic grounds became reality and do indeed have many visitors to this day. But, as a member of the trust, George could keep on arguing his point, as his children recall him to have done. The next battle came up soon, when the final stages of Henry Lawson Drive, running parallel to the river, were completed with bridges over Little Salt Pan Creek in 1963 and then the larger and more easterly Salt Pan Creek in 1964. It was initially intended that all mangrove stands on the route would be removed, leaving grassed park on both sides of the road. As George's daughter Carol remembered, he was angered that this would remove the 'reeds, the rushes and the birds' as well as the mangroves, and he campaigned tirelessly through the trust to stop it happening. This time he was at least partially successful as Colin remembers: 'And finally he had to settle for mangroves [only] on one side. But the mangroves remain there! ${ }^{29}$

27 Ed and Noeline Byron, interview, 31 May 2006.

28 Kevin, Colin and Carol Jacobsen, interview, 12 July 2006.

29 Ibid. 
The Georges River National Park Trust was a difficult place for people with strong views, as George found out. So too did a number of council appointees who held views similar to George's. The trust members came under sustained pressure to allow parts of the national park - frustratingly curtailed as it already was - to be carved off, rezoned as residential or some other zoning form that would allow development. This pressure at times took the form of offers of bribes from land developers, as George's son Colin remembered:

I recall him being evil-tempered - which the Jacobsens have a side to them of such - when he was on some committee and they offered him money to open up an area around Picnic Point, for building. And I can recall the times he stood against some kind of paint works down the end near Milperra. He said: 'They're not going to ruin that. They're going to kill our river!'30

At such times, the lessons from the damage to the Cooks River must have been starkly in the minds of Georges River residents like George Jacobsen. At other times, the pressure was less directed at individuals like George and more generally at the municipal council as a whole, which again found George battling to convince the council to purchase land being sold in order to incorporate it into the park, as Colin recalled:

I remember my father in there hammering time after time after time, going to meetings, making sure that that land [was] retained, and I'm sure it was the council he convinced into buying that block of land. He said: 'We need all this open space' ... The fact is that they realised that the land is all we've got, really. The earth is all we've got. ${ }^{31}$

\section{$\star \star \star$}

It was not only the Georges River National Park that faced pressure during the 1960s. It was a hard decade for the Royal National Park too. But the Royal was regarded very differently to the Georges River.

Arthur Gietzelt was then a senior Labor Party councillor in Sutherland Council, where he was elected president from 1961 to 1963 then again from 1966 to 1971. By tradition, the New South Wales Government

30 Ibid.

31 Ibid. This appeared to be about Innan's household block and boatshed, eventually purchased by Bankstown Council. 
invited each president of Sutherland Shire to sit on what had been renamed the 'Royal National Park' Trust after Queen Elizabeth's visit in 1954. Few former presidents had taken up this offer but Gietzelt did, becoming a trust member from 1962, a position that was independent of his shire role. He therefore continued as a trust member, whichever party held power in the shire council. For Arthur Gietzelt, the Royal National Park was important for both its social and its environmental qualities. He strongly endorsed the St George and Sutherland Shire Leader editorial:

The preservation of the 40,000 acre park, the largest and most beautiful area of its type near Sydney, is an essential recreational need for the future of both the Shire and Sydney ... The park is a wonderful part of nature - a sanctuary for 233 species of birds, many marsupials and a wide variety of Australian flora. ${ }^{32}$

His tenacity was needed, as there were intense pressures on the trust and on the park during the 1960s. His membership of the trust brought Gietzelt directly into conflict not only with private freehold landowners, developers and coal miners but also with his own council, which was seeking to quarry gravel and allow housing expansions on the Royal National Park land. At times, when his own Labor Party was not in power at either state or local government level, Gietzelt drew on support from other trust members to negotiate with the more progressive conservative (Liberal Party) politicians at both levels of government in order to retain or even expand the park area. ${ }^{33}$

The trust not only had to grapple over this time with the intractable problems of freeholder, council and mining company demands, but had to resist pressure to allow a cemetery, schools, a public golf course, youth clubs and playing fields to be built on national park lands. Through each of these conflicts, Gietzelt defended the Royal, often at personal and political loss. He proved himself to be a fighter for the environment of the same stature as George Jacobsen, contributing significantly himself, and in concert with fellow Sutherland councillors like Kevin Skinner, to the protection of the Royal National Park from the many bodies that were seeking to eat away at its edges and undermine both its social and environmental value.

32 St George and Sutherland Shire Leader (hereafter Leader), 18 August 1965, 2, cited by Gietzelt, Sticks and Stones, 185-86.

33 Gietzelt, Sticks and Stones, 181-88. 
Yet Gietzelt's attitude to the Georges River and its foreshores was very different to his attitude to the Royal. Over this same period, Sutherland Council had a core role in the Georges River National Park Trust, being one of three councils with responsibility for the park. In thinking about the northern and more densely populated area of the shire, adjacent to the Georges River, Gietzelt was most aware of that area's rising birth rate, calling it a 'generational' challenge: 'The post-war baby-boomer push for playing fields for their many children continued through the mid-sixties. It was a generational thing that many older councils rarely faced. ${ }^{34}$

In 1966, the Labor Party was re-elected in Sutherland local government elections and Gietzelt was again shire president. His close friend and ally, Kevin Skinner, was chair of the Parks and Playgrounds Committee, and both Skinner and Gietzelt felt under pressure to provide a 'home ground' for every sports code in the shire. ${ }^{35}$ The two men worked closely with the shire engineer and chief clerk to identify current shire council holdings that could be used to create such playing fields. They were all on the Georges River.

One example from 1966 that Gietzelt discusses at length was the creation of Kareela Park, which he describes as 'undulating topography'. This was a euphemism for the fact that this was the gully of a tributary of the Georges River, a small creek that ran northward into Oyster Bay. Gietzelt admitted that it was 'what some would call a wasteland' but to him and other Labor councillors it was land that 'could be made useful, indeed productive' by reclamation, by 'ripping out the rock' of the high ground and using it to level the steep gully sides and by removing 'degraded vegetation'. ${ }^{36}$ The result was four playing fields, made ready with almost miraculous speed by the application of 'instant turfing', which had 'developed an unkempt and seemingly useless bit of land'. As Gietzelt saw it, 'humankind had indeed transformed nature'. Kareela was the model for the transformation 'several times' of similar 'useless' Georges River gullies and creeks into playing fields. ${ }^{37}$

Another example was the creation of a 'home ground' for the much larger sporting body, the Cronulla-Sutherland Rugby League team, known as 'the Sharks'. The site Gietzelt believed could be transformed to make 
'Shark Park' was at Woolooware Bay, on the Georges River, on land the shire purchased from a company that had fallen bankrupt and was eager to sell. The land had been zoned 'rural' and so was protected as 'green belt' under the County of Cumberland Plan, but Gietzelt negotiated with the state government Planning Authority to have the land rezoned 'industrial'. This allowed the shire to sell a portion of it to an industrial group to build a factory, which recouped the purchase price. The remaining land was initially to be made into 23 playing fields because it was 'suitable for reclamation' - that is, it needed to be 'saved' because it was 'only' a swamp - and so it was opened as a tip for 'non-putrescent, hard-fill' household waste, comprised of 'old beds, refrigerators, washing machines and other household discards' ${ }^{38}$ Over the following year, the plan was revised to turn these 23 playing fields into the Sharks' home ground. The club had initially been unhappy, wanting somewhere close to the shopping centre, but Gietzelt talked them round. By mid-1968 the club had paid a nominal price to the shire to take over the land, becoming the only club in Australia to own its own home ground. ${ }^{39}$

It was to be precisely these local government strategies for dealing with 'useless' Georges River land - rezoning and 'reclamation' after 'ripping out' unwanted rocks and 'degraded vegetation' and dumping garbage that were to be protested against so vigorously in the later 1960s and early 1970s. Yet Gietzelt noticed little protest about the Georges River just a few years before. So perhaps the most valuable insight from his autobiography is the difference it shows between his attitudes to the Royal National Park and to the Georges River, both of which were within his responsibility as a Sutherland Shire councillor. While Gietzelt took courageous stands to defend and conserve the Royal National Park, he saw the Georges River and its bushland foreshores only as places to be 'transformed' from 'useless' and 'degraded' to 'useful and productive' to meet the 'generational' challenge.

Such attitudes seemed to the Georges River campaigners to be lurking behind the decision in 1967 to withdraw the status of 'national' from the Georges River National Park. It was known as a national park for only six years. In 1967 the New South Wales Government passed its first 
National Parks and Wildlife Act, which established the National Parks and Wildlife Service (NPWS) and formalised a hierarchy of parks with the designation of only 12 as 'national'. ${ }^{40}$ The Georges River was not on the list. The legislation enshrined 11 parks as 'national' in its new order, while 54 other parks were given the less imposing title of 'state park' or 'nature reserve'. There were three national parks in some proximity to the urban centre: Ku-ring-gai Chase and the Royal, along with the Blue Mountains National Park marking the far western limit. ${ }^{41}$

The explanation given by the government for demoting the Georges River from 'national park' to 'state park' was that the 'accepted world concept of National Parks was that they embraced spacious land areas'. ${ }^{42}$ The smallest of the 12 newly recognised national parks was 15,400 acres, the smallest of the existing 54 state parks was 1,310 acres, while Georges River National Park was as yet only 426 acres. Even with its as yet still unsecured Lewis Gordon addition, it was only ever going to be about 700 acres. ${ }^{43}$ Another category for protection was 'historic park', which denoted European 'history' not that of Aboriginal people. Kurnell qualified as 'historic' because it was the landing place of James Cook, but the Georges River parklands did not. The fantasy history invented about Cattle Duffers Flat had not impressed the state government.

The local reaction was shock. 'Bill Will Strip Park of Status' and 'Georges River Parkland Fights for Existence' screamed headlines in the St George and Sutherland Shire Leader and the Bankstown Torch. But the national park became a state park in 1967 and then was demoted again to a 'state recreation area' in 1982. The government intervened further in the structure of the trust, reducing the number of local community representatives and then, in 1987, removed the local government representation altogether.

When, in 1991, the state government finally moved to reinstate the Georges River parklands as a national park, it was at the cost of winding down the trust altogether and imposing the uniform NPWS management regime onto the parks. There was to be no more local voice, however

40 'Shock by Government: Bill Will Strip Park of Status', Leader, 4 January 1967, 13; 'Georges River Parkland Fights for Existence', Leader, 23 August 1967, 2; 'National Park Loses Status - and Finance', Bankstown Torch, 23 August 1967.

41 NPWS Table of Reserves, generated 12 October 2005, National Parks and Wildlife Service-Georges River National Park Trust (NPWS Archive), Hurstville Library, Georges River Council Libraries.

42 'Shock by Government: Bill Will Strip Park of Status', Leader, 4 January 1967, 13.

43 Ibid. 
flawed it may have been, in the management of these parks. The renewed designation of national park was widely welcomed as being more protective, but it meant the imposition of a very different management approach onto the Georges River parklands, much of which seemed more about raising revenue than about caring for the environment. ${ }^{44}$ Local response was again rapid and bitter. Labor Party parliamentarians and councillors reported that they were being inundated by public complaints from across what remained a strongly working-class population. ${ }^{45}$

Pat Rogan, state Labor member of parliament for East Hills, summarised the complaints he was receiving:

At the same time the park was established, the developers already had their eyes on this beautiful waterfront land. Having won the battle to keep this land in public ownership, the public is now being denied access to this scenic area by the increased charges. ${ }^{46}$

The shift in 1991 was depicted by opponents as a shift from a humancentred to an ecology-centred approach to park management and, in a betrayal of the people who had fought from 1950 for a park for the people who lived around it, from a more 'local' to a more distanced, state-centred orientation.

The Royal National Park survived. The tenacity of trust members like Arthur Gietzelt had kept it safe for long enough for its environmental qualities to be recognised from the 1980s and beyond. Its initial purposes, on the other hand, for recreational walks, leisurely picnics and relaxed boating have slowly been forgotten.

44 'Pat Rogan Critical over Recreation Area Changes', Bankstown Torch, 29 April 1992, 5; 'Georges River Given National Park Status', Leader, 29 October 1991.

45 R. Buchanan to Chris Hartcher, New South Wales minister for the environment, 26 August 1992, Correspondence Enquiries, Ministerial Representations - Georges River National Park, A/1732, NPWS Archive; Canterbury resident W. Aitken to Pat Rogan, member for East Hills, 10 December 1991, NPWS Archive; 'Pat Rogan Critical over Recreation Area Changes', Bankstown Torch, 29 April 1992, 5; 'Local Boaters Locked - and Priced - Out', Bankstown Torch, 5 August 1992, 3; 'Minister Asked for the Return of Recreation Area', Bankstown Torch, 31 March 1993, 9; 'Parkland Users to Offset Costs', Leader, 7 August 1968, 17.

46 'Pat Rogan Critical over Recreation Area Changes', Bankstown Torch, 29 April 1992, 5; 'Local Boaters Locked - And Priced - Out', Bankstown Torch, 5 August 1992, 3. 
This text is taken from Georges River Blues: Swamps, Mangroves and Resident Action, 1945-1980, by Heather Goodall, published 2022, The Australian National University, Canberra, Australia.

doi.org/10.22459/GRB.2021.04 